Utah State University

DigitalCommons@USU

Reports

Utah Water Research Laboratory

2014

\title{
The Sky is Falling II: Impact of Deposition Produced During the Static Testing of Solid Rocket Motors on Corn and Alfalfa
}

\author{
William J. Doucette \\ Utah Water Research Laboratory; Utah State University \\ Scout Mendenhall \\ Molzen-Corbin \\ Laurie S. McNeill \\ Utah State University \\ Justin Heavilin \\ Utah Water Research Laboratory; Utah State University
}

Follow this and additional works at: https://digitalcommons.usu.edu/water_rep

Part of the Environmental Engineering Commons

\section{Recommended Citation \\ Doucette, William J.; Mendenhall, Scout; McNeill, Laurie S.; and Heavilin, Justin, "The Sky is Falling II: Impact of Deposition Produced During the Static Testing of Solid Rocket Motors on Corn and Alfalfa" (2014). Reports. Paper 676. \\ https://digitalcommons.usu.edu/water_rep/676}

This Article is brought to you for free and open access by the Utah Water Research Laboratory at DigitalCommons@USU. It has been accepted for inclusion in Reports by an authorized administrator of DigitalCommons@USU. For more information, please contact digitalcommons@usu.edu.

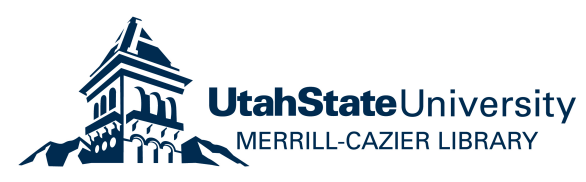


Provided for non-commercial research and education use. Not for reproduction, distribution or commercial use.

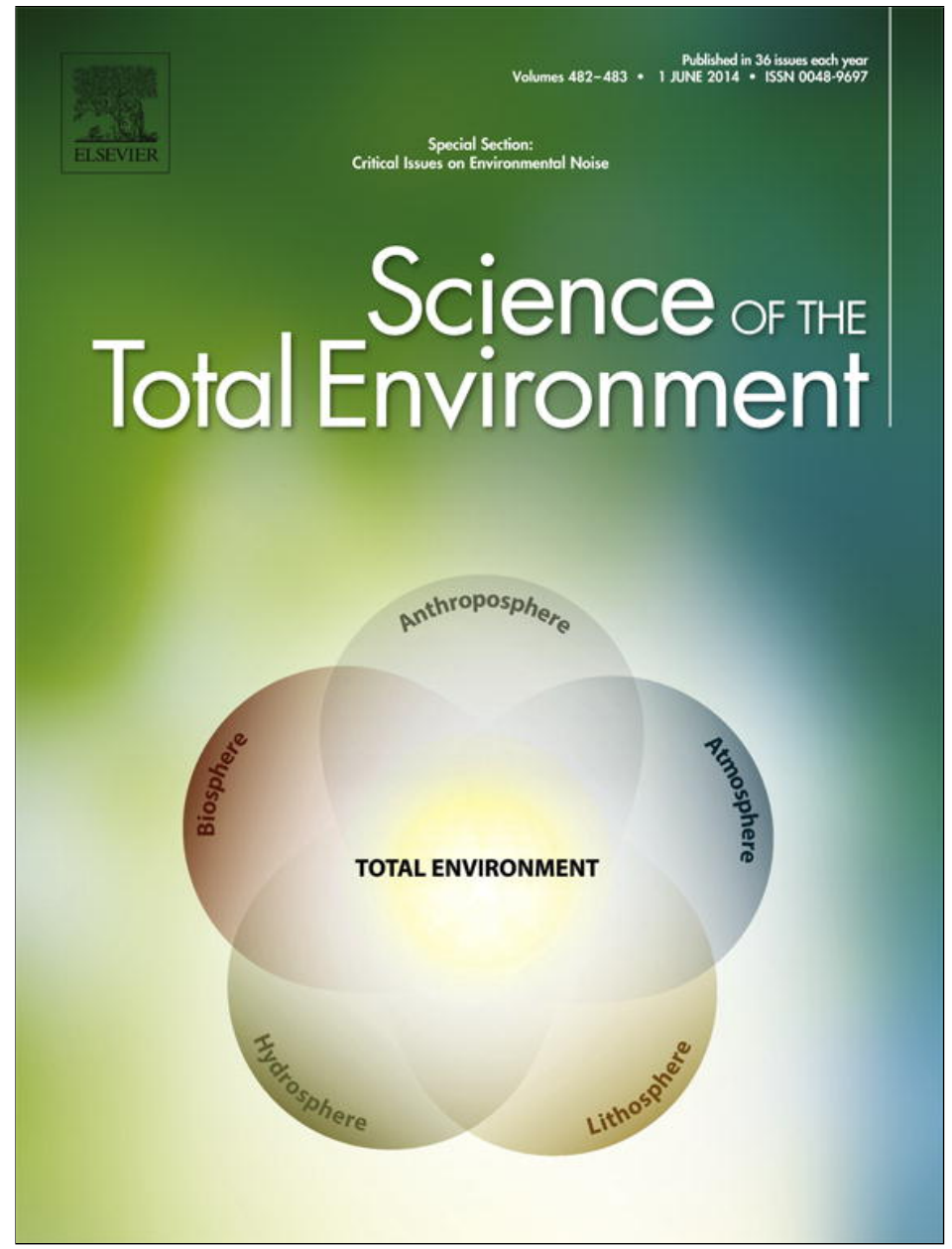

This article appeared in a journal published by Elsevier. The attached copy is furnished to the author for internal non-commercial research and education use, including for instruction at the authors institution and sharing with colleagues.

Other uses, including reproduction and distribution, or selling or licensing copies, or posting to personal, institutional or third party websites are prohibited.

In most cases authors are permitted to post their version of the article (e.g. in Word or Tex form) to their personal website or institutional repository. Authors requiring further information regarding Elsevier's archiving and manuscript policies are encouraged to visit:

http://www.elsevier.com/authorsrights 


\title{
The sky is falling II: Impact of deposition produced during the static testing of solid rocket motors on corn and alfalfa
}

\author{
William J. Doucette ${ }^{\mathrm{a}, *}$, Scout Mendenhall ${ }^{\mathrm{b}}$, Laurie S. McNeill ${ }^{\mathrm{a}}$, Justin Heavilin ${ }^{\mathrm{a}}$ \\ a Utah Water Research Laboratory, Utah State University, 8200 Old Main Hill, Logan, UT 84322, USA \\ b Molzen-Corbin, 2701 Miles Road SE, Albuquerque, NM 87106, USA
}

\section{H I G H L I G H T S}

- Static rocket motor tests deposit entrained soil and combustion products on crops.

- High deposition exposures could impact corn and alfalfa germination and growth.

- High chloride in the deposition is the main cause of the observed impacts.

- Depositional impacts can be mitigated with rainfall or additional irrigation water.

\section{A R T I C L E I N F O}

\section{Article history:}

Received 24 October 2013

Received in revised form 16 January 2014

Accepted 17 February 2014

Available online 15 March 2014

\section{Keywords:}

Rocket motor testing

Atmospheric deposition

Corn

Alfalfa

Chloride

Aluminum

\begin{abstract}
A B S T R A C T
Tests of horizontally restrained rocket motors at the ATK facility in Promontory, Utah, USA result in the deposition of an estimated 1.5 million kg of entrained soil and combustion products (mainly aluminum oxide, gaseous hydrogen chloride and water) on the surrounding area. The deposition is referred to as test fire soil (TFS). Farmers observing TFS deposited on their crops expressed concerns regarding the impact of this material. To address these concerns, we exposed corn and alfalfa to TFS collected during a September 2009 test. The impact was evaluated by comparing the growth and tissue composition of controls relative to the treatments. Exposure to TFS, containing elevated levels of chloride (1000 times) and aluminum ( 2 times) relative to native soils, affected the germination, growth and tissue concentrations of various elements, depending on the type and level of exposure. Germination was inhibited by high concentrations of TFS in soil, but the impact was reduced if the TFS was pre-leached with water. Biomass production was reduced in the TFS amended soils and corn grown in TFS amended soils did not develop kernels. Chloride concentrations in corn and alfalfa grown in TFS amended soils were two orders of magnitude greater than controls. TFS exposed plants contained higher concentrations of several cations, although the concentrations were well below livestock feed recommendations. Foliar applications of TFS had no impact on biomass, but some differences in the elemental composition of leaves relative to controls were observed. Washing the TFS off the leaves lessened the impact. Results indicate that the TFS deposition could have an effect, depending on the amount and growth stage of the crops, but the impact could be mitigated with rainfall or the application of additional irrigation water. The high level of chloride associated with the TFS is the main cause of the observed impacts.
\end{abstract}

(C) 2014 Elsevier B.V. All rights reserved.

\section{Introduction}

Since 1977, over 50 static ground tests of large solid rocket motors have been conducted at the Alliant Techsystems (ATK) Promontory, Utah facility to evaluate and improve the performance and safety of reusable solid rocket motors (RSRMs) used in NASA's space program. During these 2-minute tests, heavily instrumented RSRMs, containing over $680,000 \mathrm{~kg}$ of an ammonium perchlorate-aluminum based

\footnotetext{
* Corresponding author. Tel.: +1 435797 3178; fax: +1 4357973663

E-mail address: william.doucette@usu.edu (W.J. Doucette).
}

propellant, are horizontally restrained and ignited while performance data are collected.

A high-temperature cloud of combustion products, mainly aluminum oxide $\left(\mathrm{Al}_{2} \mathrm{O}_{3}\right)$, hydrogen chloride $(\mathrm{HCl})$ and water and an estimated 1.5 million $\mathrm{kg}$ of entrained soil are generated. After reaching heights of $3000-4600 \mathrm{~m}$ above ground surface, the cloud cools, and the deposition material drops on the surrounding area, which includes farmland where corn and alfalfa are primary crops.

The depositional rate, moisture content of the deposition material, and area impacted by deposition (usually at a $10-20^{\circ}$ angle that extends out to $16-20 \mathrm{~km}$ ) vary from test to test depending on the prevailing weather conditions. Characterization of the deposition material, 
referred to as test fire soil (TFS), collected from four static tests conducted in 2009-2011 showed that chloride concentrations in the TFS $(25,000$ to $69,000 \mathrm{mg} / \mathrm{kg}$ ) were three orders of magnitude greater than in the soil collected just outside the static test site impacted area and aluminum concentrations in the TFS $(31,000 \pm 65,000 \mathrm{mg} / \mathrm{kg})$ were approximately twice that of the non-impacted soil (Doucette et al., 2013).

Despite $\mathrm{HCl}$ being formed during combustion, it was also observed that the pH of TFS samples measured shortly after collection was sometimes higher than native soils from the area. The higher $\mathrm{pH}$ observations are due to the high-temperature conversion of calcite to calcium oxide that, in turn, reacts with water to form calcium hydroxide. Over time, the $\mathrm{pH}$ of the TFS declines to levels near that of the original soil as atmospheric carbon dioxide is absorbed and calcite is reformed.

Chloride is an essential micronutrient for crop plants that is rarely deficient in soils but can be toxic in excess levels (White and Broadley, 2001). Chloride shows little sorption to soils and moves within soils as a function of precipitation and evapotranspiration. Responses of plants to chloride vary widely, with differences often attributed to the ability to restrict chloride transport to the shoot (White and Broadley, 2001). Critical tissue chloride concentrations for toxicity are about 4-7 and 15-50 mg/g dry-weight for chloride-sensitive and chloride-tolerant plant species, respectively (White and Broadley, 2001). In some cases, the effects of high chloride on plants may be lessened if sufficient nutrients are available (Kinraide, 1999; Munns, 2002). For example, calcium has been reported to mitigate salt stress in some species (Melgar et al., 2007; Tattini and Traversi, 2008). Numerous studies have examined the impact of salinity on plant health where both the cation (typically sodium) and the anion forms (chloride) have different physiological roles. In a study with two varieties of faba bean that differed in salinity tolerance, Tavakkoli et al. (2010) suggested that high concentrations of sodium and chloride limit growth through different mechanisms. High concentrations of sodium interfere with potassium and calcium nutrition, while high chloride concentrations reduce the photosynthetic capacity due to chlorophyll degradation. However, in the case of TFS deposition, the source of chloride is hydrochloric acid, so sodium stress is not expected to be a concern.

Aluminum $(\mathrm{Al})$ is not a plant nutrient, and toxicity is a concern in acidic soils, where $\mathrm{Al}$ is in a mobile and readily exchangeable form (Langer et al., 2009; Mora et al., 1999). Aluminum can inhibit plant root development, water and nutrient uptake, and overall plant growth (Delhaize and Ryan, 1995). Aluminum toxicity has been reported to stunt growth in several crops, including wheat (Miyasaka et al., 1989), barley (Ali et al., 2011), soybean (Abo et al., 2010), and corn (Bennet et al., 1987). However, since the soils in the area around the ATK test site are neutral or alkaline, the mobility of aluminum within soils and its availability to plants are expected to be very low.

Direct contact between the plant foliage and the TFS is another potential route of exposure. Leaves are protected by a waxy cuticle that minimizes water loss and leaching of minerals from plant tissue (Marschner, 2012). However, the cuticle is not impervious, and chemicals deposited on leaves may permeate into plant cytoplasm (Noack et al., 2010). As an example, foliar application of nutrients has been used to improve plant nutrition, especially when nutrients are not readily available in soil (Fernández and Eichert, 2009; Marschner, 1995; Marschner, 2012). Direct exposure to saline water from a sprinkling irrigation system injured corn (Isla and Aragüés, 2010) and alfalfa (Isla and Aragüés, 2009). Environmental factors such as relative humidity, temperature, and age of the leaf affect the thickness and permeability of the cuticle (Devine et al., 1993).

To address the concerns of local farmers observing TFS deposited on their fields and/or crops, greenhouse studies were conducted to expose corn and alfalfa to various applications (soil and foliar) of TFS collected during a September 2009 test. The impact of the TFS was evaluated by comparing the growth and tissue composition (i.e. nutrient content, metals, anions) of controls relative to the treatments.

\section{Materials and methods}

\subsection{Test fire soil (TFS) collection}

Polyethylene tarps $\left(3 \mathrm{~m}^{2}\right)$, placed on the ground at various locations just before the start of the static motor test, were used to collect TFS for chemical characterization and for use in the germination and greenhouse studies. To obtain sufficient material to conduct the studies, TFS was also collected from various flat surfaces such as rooftops, sidewalks and driveways within the TFS impacted areas.

\subsection{Seed germination studies}

Following the general guidelines outlined in the 120-hour Standard Toxicity Test for lettuce seed germination (U.S. Environmental Protection Agency, 1987), three studies were conducted to evaluate the potential impact of TFS on corn and alfalfa seed germination. The TFS was collected during the September 2009 DM-1 static test and contained $56,100 \mathrm{mg} / \mathrm{kg}$ chloride and $65,100 \mathrm{mg} / \mathrm{kg}$ aluminum (Doucette et al., 2013).

The first germination test evaluated four TFS amended soil mixtures ( $50 \%, 10 \%, 2 \%$, and $0.4 \%$ TFS by weight in soil), in addition to a soil only control. The soil used was a local sandy loam ( $\mathrm{pH} 7.0$, electrical conductivity $0.90 \mathrm{dS} / \mathrm{m}, 1.7 \%$ organic matter). Triplicate Petri dishes $(150 \mathrm{~mm}$ $\times 15 \mathrm{~mm}$ ) each received $100 \mathrm{~g}$ of various soil or TFS amended soil mixtures along with 20 corn kernels or 40 alfalfa seeds. The seeds were gently pressed into the soil using the bottom of a $600-\mathrm{mL}$ glass beaker. The seeds and soil were gently moistened with $30 \mathrm{~mL}$ de-ionized water then covered with $90 \mathrm{~g}$ of sand. Each set of triplicate Petri dishes was placed in a one-gallon Ziploc ${ }^{\mathrm{TM}}$ bag and sealed, leaving as much air as possible in the bag. The bagged Petri dishes were placed in a darkened growth chamber at $24 \pm 2{ }^{\circ} \mathrm{C}$. The growth chamber remained dark for $48 \mathrm{~h}$, followed by $16 \mathrm{~h}$ of light and $8 \mathrm{~h}$ of darkness for the remainder of the test. The seedlings were then counted and percent germination was determined. As specified in the US EPA germination test guidelines, germination was defined as the observance of plant material above the sand layer.

Following the same procedure described above, a second germination test was performed to specifically evaluate the impact of the two major TFS components: chloride (added as $\mathrm{HCl}$ ) and aluminum (added as $\mathrm{Al}_{2} \mathrm{O}_{3}$ ). In addition to the soil only control, four types of soil amendments were evaluated: soil amended with $10 \%$ TFS (for comparison to the first germination study); soil amended with $\mathrm{Al}_{2} \mathrm{O}_{3}$; soil amended with $\mathrm{HCl}$; and soil amended with the combination of $\mathrm{Al}_{2} \mathrm{O}_{3}$ and $\mathrm{HCl}$. Each of the $\mathrm{HCl}, \mathrm{Al}_{2} \mathrm{O}_{3}$ and $\mathrm{Al}_{2} \mathrm{O}_{3}+\mathrm{HCl}$ amendments was made at three different soil concentrations within a target range of $65-6500 \mathrm{mg}$ $\mathrm{Cl}$ or $\mathrm{Al} / \mathrm{kg}$. The concentration range was designed to include the equivalent chloride and aluminum concentrations resulting from the $10 \%$ to $0.4 \%$ TFS amended soil treatments used in the first germination test.

The third test examined the potential impact of leaching (from rainfall or irrigation) prior to seed introduction on the germination of corn and alfalfa planted in TFS impacted soil. Soil for this test was generated using a standard column leaching protocol (US Environmental Protection Agency, 2008). Columns were constructed of clear plastic pipe (6-cm diameter) cut into $30 \mathrm{~cm}$ lengths and covered at the bottom with Whatman 42 filter paper, tightly secured using rubber bands. Four replicate columns of each treatment (soil, 10\% TFS amended soil mixture and soil with $1 \mathrm{in}$. TFS added to the surface) were carefully filled to minimize voids. Artificial rainwater $\left(0.01 \mathrm{M} \mathrm{CaCl}_{2}\right)$ was applied at a rate of $0.2 \mathrm{~mL} / \mathrm{min}$ using a Cole Parmer Masterflex L/S peristaltic pump (Barnant Co, Barrington, IL) for $48 \mathrm{~h}$, simulating a $200 \mathrm{~mm}$ rain or irrigation event over 2 days. Filter paper was placed on top of the soil to spread the water over the surface of the column. The top $3 \mathrm{~cm}$ of "leached" soil from each set of replicate columns was collected, combined, homogenized and used to conduct a germination test following the procedure described previously. 


\subsection{Greenhouse growth study}

A greenhouse study was performed to determine the impact of TFS on the biomass production and composition (chloride, aluminum, and other metals) of corn and alfalfa under two soil and foliar exposure scenarios. Exposures to TFS through the soil consisted of soil amended with $10 \%$ TFS ( 1 in. TFS tilled into $10 \mathrm{in}$. of surface soil) and soil with $1 \mathrm{in}$. TFS added to the soil surface after 54 days (approximately halfway to plant maturity). The TFS applications were based on a worst case estimate reported by a local farmer. The controls for these exposures were corn and alfalfa grown in soil without TFS. Foliar exposures consisted of TFS applied to foliage after 54 days (corn) or 130 days (alfalfa) and TFS applied to foliage after 54 days then rinsed off with water after one week (simulated rain event). Controls for these exposures were soil applied to the foliage instead of TFS. Due to greenhouse space limitations, the foliar application to alfalfa was conducted in a separate set of experiments approximately three months later. All exposure scenarios were performed in triplicate for a total of 30 columns. The TFS used in this study was collected during the September 2009 DM-1 test.

\subsubsection{Plant growth environment}

Corn and alfalfa were grown in $12.7 \mathrm{~cm}$ by $1.22 \mathrm{~m}$ ( 5 in. by $4 \mathrm{ft}$ ) PVC columns capped at one end and equipped with a port for drainage. Columns were packed with moistened soil and fertilizer (Osmocote 15-9-12 NPK, 3-4 month release) prior to planting. The soil used to grow alfalfa was the same local sandy loam soil used in the germination studies, and the soil used to grow the corn was a Collett silty clay loam taken from a corn field located in Thatcher, UT ( $\mathrm{pH}$ 8.1, electrical conductivity $2.3 \mathrm{dS} / \mathrm{m}, 1.6 \%$ organic carbon). Thatcher, UT is about 5 miles northeast of the test site and it is located in an area that has received the TFS deposition during rocket motor testing. The soil was collected from an active cornfield with permission and assistance from the owner.

As the soil was added, the columns were periodically lifted up $2.5-5 \mathrm{~cm}$ off the floor and dropped to help uniformly distribute the soil. Five grams of fertilizer was added at four intervals starting about $30 \mathrm{~cm}$ from the bottom of the column. One of each three triplicate columns was equipped with EC-5 Soil Moisture Sensors (Decagon Devices, Pullman, WA) placed 15 and $33 \mathrm{~cm}$ from the top of the soil.

Three corn (Zea mays, cv. 'Dekalb 5259') or alfalfa seeds (Medicago sativa, cv. 'Rugged') were planted per column, equally spaced and approximately $3.8 \mathrm{~cm}$ (corn) or $2.2 \mathrm{~cm}$ (alfalfa) deep. The soil surfaces were gently sprayed with tap water, and the columns were covered tightly with aluminum foil to prevent the seeds from drying out. The foil was removed when at least one seed germinated. Corn plants were thinned to one per column 27 days after sowing.

An automated irrigation system consisting of pressure compensating drippers, solenoids and a CR1000 datalogger/multiplexer (Campbell Scientific, Logan, UT) supplied water to the columns. When the lower soil moisture sensor dropped below a volumetric water content (VWC) value of 0.15 , the drippers released water at the column surface for $4 \mathrm{~min}$ at a rate of $33 \mathrm{~mL} / \mathrm{min}$. This allowed water to penetrate the column and encouraged development of a deep root system. A $3 \times$ $4 \mathrm{~cm}$ piece of a Scotch-Brite ${ }^{\mathrm{TM}}$ pad was placed under the drippers to spread the water more evenly over the soil surface. To minimize the number of soil moisture probes used, only one column per triplicate set was instrumented. It was also observed that the moisture probe measurements were unreliable in the presence of TFS, so plants treated with TFS were watered based on probe readings in the control plant columns. The moisture sensors installed in the columns measure the volumetric water content of the soil by measuring the dielectric constant of the soil, which is a strong function of water content. The sensor manufacturer recommends that users conduct a soil-specific calibration for best possible accuracy and all probes were calibrated based on the initial conditions in the column. The moisture probe readings were unstable in the columns containing TFS likely due to the relatively rapid variation in soil water ionic strength associated with watering the columns containing TFS. The moisture probe readings in the soil-only controls were considerably more stable and were used to control the watering of all columns.

Foliar treatment of corn occurred after 54 days of summer sunlight, while the foliar treatment of alfalfa occurred after 130 days of growth in winter sunlight. The plants were lightly misted with de-ionized water before application of soil or TFS directly to foliage. Paper bags were cut and folded into cones around the plants to catch falling soil and TFS, minimizing direct deposition to the soil surface. Soil and TFS were sprinkled over the plant tissue by hand to yield a coverage visually matching field observations. One week after foliage treatment, two sets of triplicate plants (one set treated with soil, the other with TFS) were gently rinsed with tap water using a water wand to remove the deposition. The soil in the columns was covered with plastic to prevent TFS or soil from washing into the root zone of the plants.

\subsubsection{Collection and analysis of plant samples}

Corn leaves were collected at 60, 90 and 130 (final harvest) days after planting for all treatments except $10 \%$ TFS, which could not be sampled at any of the times due to insufficient leaf mass. At least two leaves (youngest) were collected to supply a sufficient mass for analysis. Mature ears of corn were also harvested at 130 days. A razor blade was used to cut corn leaves from the plant above the collar of the leaf to minimize stalk damage. At the end of the experiment, the ears of corn were collected and shelled to compare treatment effects on the production of kernels. The corn was dried on the plant for 2 weeks before transferring to an oven at $60{ }^{\circ} \mathrm{C}$ for 5 days. The kernels were shelled off the cob and weighed.

The first alfalfa sampling occurred 52 days after planting, just before the addition of TFS on the soil surface on day 54. Alfalfa was cut to a height of $10.2 \mathrm{~cm}$ ( $4 \mathrm{in}$.) with a razor blade. Two more cuttings were collected 87 and 119 (final harvest) days from planting. Leaves from each column were combined and homogenized for analysis.

Plant tissue samples were rinsed with de-ionized water and placed into a paper bag that had been labeled and weighed. The bag and rinsed plant material were dried in a forced-air oven (Model 1390FM, VWR Scientific, Radnor, PA) at $80{ }^{\circ} \mathrm{C}$ for $48 \mathrm{~h}$ to determine the dry weight of the plant tissue. Plant material was homogenized using a Thomas Wiley ${ }^{\circledR}$ Mini Mill (Arthur H. Thomas Co., Philadelphia, USA) prior to analysis.

A subsample $(0.5 \mathrm{~g})$ of each plant tissue sample was digested with nitric acid and hydrogen peroxide following the EPA Method 3050b (U.S. Environmental Protection Agency, 2012a) and analyzed for metals using an Iris Intrepid II Inductively-Coupled Plasma Atomic Emission Spectrometer (ICP-AES) (Thermo Electron, Madison, WI). Detection limits for the ICP-AES are listed in Table S1. A separate subsample was analyzed for Total Nitrogen by combustion using a LECO TruSpec C/N Analyzer (LECO Corporation, St. Joseph, MI).

For chloride analysis, 1-gram samples of air-dried plant or soil samples were added to $10 \mathrm{~mL}$ of deionized water (DI) in $50 \mathrm{~mL}$ polyethylene centrifuge tubes. The tubes were agitated for $48 \mathrm{~h}$ on a rotary tumbler operating at $40 \mathrm{rpm}$, then centrifuged at $4000 \mathrm{rpm}$ for $20 \mathrm{~min}$ to separate the phases. An aliquot of supernatant, filtered through a $0.2-\mu \mathrm{m}$ nylon syringe filter and diluted, if necessary, to stay within the instrument calibration range, was analyzed by using a Dionex DX500 Ion Chromatography system equipped with a $50 \mathrm{~mm}$ guard column, 4 $\times 250 \mathrm{~mm}$ S11-HC analytical column and a CD20 conductivity detector. The isocratic elution program utilized a $30 \mathrm{mM} \mathrm{NaOH}$ solution at a flow rate of $1.5 \mathrm{~mL} / \mathrm{min}$.

A microwave digestion procedure, patterned after the EPA Method 3050b (U.S. Environmental Protection Agency, 2012a), was used for all soil and TFS samples. Approximately $0.5 \mathrm{~g}$ solid was placed in a $75 \mathrm{~mL}$ PTFE vessel (APCU-40 TFM, Milestone, Italy). Sides of the vessel were rinsed with $5 \mathrm{~mL}$ de-ionized water, followed by the addition of $9 \mathrm{~mL}$ concentrated nitric acid (trace metal grade, Fisher Scientific) and $2 \mathrm{~mL}$ 
hydrogen peroxide $30 \%$ by weight (trace metal grade, Fisher Scientific). The vessels were capped, placed in an Ethos EZ Microwave Digestion System (Milestone, Italy) and gradually heated to $200{ }^{\circ} \mathrm{C}$ over $15 \mathrm{~min}$. After $30 \mathrm{~min}$ at $200{ }^{\circ} \mathrm{C}$ and a 20 -min cool-down period, samples were diluted to $100 \mathrm{~mL}$ and filtered (Whatman No. 42) before analysis by inductively coupled plasma-mass spectrometry (ICP-MS) following the EPA Method 6020 (U.S. Environmental Protection Agency, 2012b). The Agilent 7500c ICP-MS was calibrated using external standards prepared from a certified stock (High-Purity Standards, Charleston, SC). Internal standards were Sc, Ge, In, and Tb. Helium collision mode was used to remove interferences for the analysis of $\mathrm{V}, \mathrm{Cr}, \mathrm{Mn}, \mathrm{Fe}, \mathrm{Co}, \mathrm{Ni}, \mathrm{Cu}, \mathrm{Zn}$, and As. Hydrogen reaction mode was used for the Se analysis. All other metals were analyzed without the reaction cell. Quality control samples included blanks, calibration verification samples, and duplicate matrix spikes.

\subsubsection{Statistical analysis}

Statistical analyses were performed using R statistical software. Significant differences were determined by ANOVA and Tukey's Honest Significant Difference tests (both at $\mathrm{p}<0.05$ ).

\section{Results and discussion}

\subsection{Germination studies}

The results of the first 5-day germination test for corn and alfalfa exposed to several TFS amended soil mixtures are summarized in Table S2. Corn germination was unaffected in the $0.4 \%$ or $2.0 \%$ TFS amended soil treatments, but no germination was observed in $10 \%$ or $50 \%$ treatments. Alfalfa germination was reduced by over $35 \%$ at the $0.4 \%$ TFS amended soil treatment and no germination was observed in any of the higher TFS concentrations.

Designed to specifically examine the effect of aluminum and chloride, the second germination study found that aluminum had no measurable effect over the concentrations investigated, while chloride concentrations of $2000-3000 \mathrm{mg} / \mathrm{kg}$ soil reduced alfalfa germination to $40-50 \%$ and completely prevented germination above $6000 \mathrm{mg} / \mathrm{kg}$ (Table S3). Corn germination was reduced to $<20 \%$ by chloride above $2500 \mathrm{mg} / \mathrm{kg}$. The $6000 \mathrm{mg} / \mathrm{kg}$ chloride concentration is similar to the chloride concentration in the 10\% TFS amended soil treatment.

Results of the third test show that the germination of corn and alfalfa in the TFS amended soil mixtures increased after leaching with the simulated rain or irrigation water. After 5 days, 80-90\% of the corn and alfalfa in the "leached" $10 \%$ TFS amended soil had sprouted, equivalent to the leached soil controls. Even the 100\% TFS showed 40-50\% germination after the simulated rainfall event. By 7 days, there was no statistical difference between the "leached" $100 \%$ TFS, $10 \%$ TFS amended soil mixture and the non-amended soil for corn germination. Although the germination percentage of corn in leached $100 \%$ TFS was no different than the $10 \%$ TFS amended soil mixture after seven days, the seedlings were visibly smaller. In addition, alfalfa germination was still statistically lower $(\mathrm{p}<0.05)$ in leached 100\% TFS than 10\% TFS amended soil mixture or non-amended soil.

\subsection{Corn and alfalfa biomass production}

Corn biomass production was significantly reduced (see Table 1 ) by the TFS amended soil treatments ( $10 \%$ and 1 in. applied to surface), while the TFS foliar applications had no statistical impact (Tables 1 and 2). It can also be observed in Table 3 that the biomass production for the greenhouse control corn plants was similar to corn grown in the field, indicating that an adequate growth environment was provided.

Corn grown in the 10\% TFS amended soil produced tassels, silks, and undeveloped ears, but growth was delayed 25-30 days relative to the controls. Corn treated with TFS on the soil surface at day 54 produced fewer mature leaves (9-10) than the control plants (14-15), and new leaves that formed after the TFS surface application were discolored, with only one fully mature leaf being produced.

The foliar application of soil (control for physical blockage of light) or TFS did not impact the corn biomass produced, but the TFS application appeared to "burn" the leaves at the point of contact. The damaged appearance did not change after washing; however, the new leaves that formed later appeared normal. It should be noted that in a greenhouse, where humidity is generally higher than the field, plants produce less wax. As a result, greenhouse plants may be more susceptible to foliar exposures.

Field, control, and foliage-treated plants produced mature ears of corn with statistically equivalent masses, but the plants treated with TFS amended soil or with TFS applied to the soil surface had no significant yields of corn ears, although one plant grown in $10 \%$ TFS produced an ear containing $1.6 \mathrm{~g}$ of kernels.

Alfalfa production was also impacted by the TFS soil exposure (Table 2). Alfalfa did not sprout in 10\% TFS amended soil mixture, consistent with the germination studies. One-week-old alfalfa plants that were germinated on paper and transplanted into 10\% TFS amended soil mixture did survive but produced significantly less plant material than the controls. TFS applied to the soil surface after 54 days reduced alfalfa biomass production during the second sampling period (87 days after planting), but by the third sampling period (119 days after planting), the differences were not statistically significant $(p>0.05)$. As expected, the alfalfa biomass produced during the first sampling period (52 days) was equivalent to the control plants since the TFS was not applied until day 54 .

The impact of foliar deposition of soil and TFS on alfalfa was evaluated in a separate study due to greenhouse space limitations. No impact on alfalfa biomass production from the foliar deposition of soil or TFS was observed. However, this study was conducted during the winter months, and less biomass was produced than in the previous study conducted during summer months.

Another possible impact of TFS deposition that was not specifically investigated is the potential for the deposition to slow the diffusion of

Table 1

Total corn biomass production per column at final harvest ${ }^{\mathrm{a}}$ by treatment.

\begin{tabular}{|c|c|c|c|c|}
\hline \multirow[b]{2}{*}{ Treatment type } & \multicolumn{2}{|c|}{ Kernels (g, dry) } & \multicolumn{2}{|c|}{$\begin{array}{l}\text { Above ground biomass excluding kernels } \\
\text { (g, dry) }\end{array}$} \\
\hline & Average & St. Dev & Average & St. Dev \\
\hline Control (soil) & $117.6^{\mathrm{a}}$ & 15.5 & $99.4^{\mathrm{a}}$ & 11.2 \\
\hline $10 \% \mathrm{TFS}$ & $0.5^{\mathrm{b}}$ & 1.1 & $4.8^{\mathrm{b}}$ & 4.3 \\
\hline TFS on soil & $0^{\mathrm{b}}$ & 0 & $43.9^{c}$ & 16.9 \\
\hline Soil deposition & $122.8^{\mathrm{a}}$ & 10.6 & $113.0^{\mathrm{a}}$ & 11.8 \\
\hline Soil deposition + wash & $115.5^{\mathrm{a}}$ & 9.8 & $92.2^{\mathrm{a}}$ & 1.8 \\
\hline TFS deposition & $130.2^{\mathrm{a}}$ & 17.1 & $105.2^{\mathrm{a}}$ & 7.5 \\
\hline TFS deposition + wash & $119^{\mathrm{a}}$ & 9.1 & $118.9^{\mathrm{a}}$ & 4.3 \\
\hline Field corn & $138.4^{\mathrm{a}}$ & 69.6 & $92.1^{\mathrm{a}}$ & 22.2 \\
\hline
\end{tabular}

Note: average values within a column of data followed by the same lower case letter are not significantly different according to ANOVA and Tukey's test ( $\mathrm{p}<0.05$ ).

a Final harvest times: 130 days for corn and 119 days for alfalfa. 
Table 2

Alfalfa biomass production per column by treatment.

\begin{tabular}{llll}
\hline Treatment type & First sampling (52 days) & & \multicolumn{2}{c}{ Second sampling (87 days) } \\
\cline { 2 - 3 } & $(\mathrm{g})$ & $(\mathrm{g})$ & \multicolumn{1}{c}{ Third sampling (119 days) } \\
\hline Control (soil) & $6.0^{\mathrm{a}}$ & $2.8^{\mathrm{a}}$ & $2.5^{\mathrm{b}}$ \\
$10 \%$ TFS & $0.0^{\mathrm{b}}$ & $4.5^{\mathrm{b}}$ & $2.2^{\mathrm{b}}$ \\
TFS on soil & $6.2^{\mathrm{a}}$ & $11.7^{\mathrm{ab}}$ \\
\hline
\end{tabular}

Note: Within sampling events, values followed by the same lower case letter are not significantly different according to ANOVA and Tukey's test ( $\mathrm{p}<0.05$ ).

oxygen into the soil. Many plants do not grow well in oxygen deficient soil conditions (Taiz and Zeiger, 2006). However, some plants, like corn, develop aerenchyma, air spaces between cells that provide transport of oxygen from shoots to the roots (Justin and Armstrong, 1987), if soil conditions become flooded or otherwise oxygen deficient (Fukao and Bailey-Serres, 2004). Since alfalfa does not develop aerenchyma (Torabi et al., 2011), alfalfa would likely be more impacted than corn if TFS deposition reduces oxygen transfer into the soil. This was not observed and suggests that oxygen transfer through TFS is not much different than soil.

\subsection{Leaf tissue composition (chloride, metals, and nutrients)}

Corn and alfalfa leaf tissue were analyzed for selected anions, metals, and nutrients, with a focus on chloride and aluminum, rocket fuel combustion products that are found in higher concentrations in the TFS than in the soil (Tables S4, S5, and S6).

As expected, the biggest difference between the controls and the TFS exposed (soil and foliar) plants was in chloride concentrations (Table 3). For TFS amended soil-exposed corn and alfalfa, chloride concentrations in the leaves were one or two orders of magnitude greater than the respective controls. Corn and alfalfa leaves exposed to TFS deposition were also higher than the controls but only by a factor of 10 , suggesting that chloride uptake by roots is likely to be more important than foliar uptake in the field deposition situations. However, even the highest observed chloride concentrations $(70,000 \mathrm{mg} / \mathrm{kg}$ in plants exposed to TFS on the soil surface) were still within the wide range (2000-200,000 mg/kg dry weight) of literature reported values (Marschner, 1995).

Only one undeveloped ear, containing $1.6 \mathrm{~g}$ of kernels (insufficient weight for analysis), was produced by the six TFS amended soilexposed corn plants grown in the greenhouse. The highest kernel chloride concentration was found in the corn that had foliage treated with TFS after 54 days and washed off with water a week later. This could be the result of chloride in the TFS deposition being solubilized during the washing and then moving into the cob. While higher than the controls, the chloride concentrations were no greater than those found in corn grown in the field. Corn plants treated with foliar TFS deposition

Table 3

Average chloride content in corn and alfalfa leaf tissue and corn kernels.

\begin{tabular}{lcll}
\hline & \multicolumn{2}{c}{ Chloride $(\mathrm{mg} / \mathrm{kg})$} & \\
\cline { 2 - 4 } Treatment & Corn leaf tissue & Corn kernels & Alfalfa leaf tissue \\
\hline Control & $481 \pm 241^{\mathrm{b}}$ & $511 \pm 49.2^{\mathrm{ab}}$ & $627 \pm 31.0^{\mathrm{a}}$ \\
$10 \%$ TFS & $69600 \pm 28900^{\mathrm{e}}$ & None produced & $15040 \pm 7500^{\mathrm{b}}$ \\
TFS on soil & $70100 \pm 23200^{\mathrm{e}}$ & None produced & $11740 \pm 408^{\mathrm{b}}$ \\
Soil deposition & $138 \pm 101^{\mathrm{a}}$ & $379 \pm 18.2^{\mathrm{a}}$ & No treatment \\
Soil deposition + wash & $201 \pm 25.4^{\mathrm{ab}}$ & $431 \pm 50.5^{\mathrm{a}}$ & No treatment \\
TFS deposition & $4800 \pm 658^{\mathrm{d}}$ & $656 \pm 56.7^{\mathrm{bc}}$ & No treatment \\
TFS deposition + wash & $1560 \pm 436^{\mathrm{c}}$ & $772 \pm 19.3^{\mathrm{c}}$ & No treatment \\
Field (Thatcher, UT) & $1860 \pm 599^{\mathrm{cd}}$ & $606 \pm 111^{\mathrm{bc}}$ & None collected \\
\hline
\end{tabular}

Note: Within leaf tissues or corn kernels, values (average \pm standard deviation) followed by the same lower case letter are not significantly different according to ANOVA and Tukey's test $(p<0.05)$. Alfalfa concentrations were determined in leaf tissue collected after third cutting. Deposition treatments were not conducted for the alfalfa. (washed and unwashed) produced kernels containing statistically higher zinc than controls (Table S4).

Concentrations of aluminum in the corn plant leaves exposed to the TFS through soil treatments $(181 \pm 123 \mathrm{mg} / \mathrm{kg})$ were not significantly different from the controls $(151 \pm 103 \mathrm{mg} / \mathrm{kg})$, even though the aluminum levels in the TFS were twice that in the soils. Similarly, aluminum levels in the leaves were not different in TFS-exposed alfalfa plants $(16 \pm 4 \mathrm{mg} / \mathrm{kg}$ ) compared to the control (16 $\pm 7 \mathrm{mg} / \mathrm{kg})$. This is not surprising considering the low mobility of aluminum in alkaline soils. However, it is interesting to note that the concentrations of aluminum were higher in corn plant leaves exposed directly to the foliar deposition. Plant leaves exposed directly to TFS deposition (unwashed) contained more aluminum ( $1336 \pm 424 \mathrm{mg} / \mathrm{kg}$ ) than the controls and other treatments, including TFS deposition that was washed off after one week $(218 \pm 43 \mathrm{mg} / \mathrm{kg})$. Iron was also elevated in plant leaves in direct contact with TFS deposition (unwashed), but a similar increase in iron concentration was also observed in plants treated with a foliar application of soil. Iron is often applied to foliage in cases of limited soil availability (Fernández and Eichert, 2009), showing its ability to move from leaves to shoots.

Several other elements were also found in statistically higher concentrations in plants grown in $10 \%$ TFS amended soil or treated with TFS on the soil surface relative to the controls, including the cations barium, calcium, cadmium, potassium, strontium, and zinc (Tables S4-S6). However, since the concentrations of these elements in the TFS were not significantly different than the soil, the higher uptake was likely a plant response to counter the charge imbalance associated with the accumulation of chloride. The National Research Council (NRC, 2005) has developed maximum tolerable levels (MTL) for elements that can be fed to livestock without impairing animal health. For corn and alfalfa, none of the plant tissue concentrations measured in this study exceeded the MTLs.

\section{Conclusions}

Exposure to TFS, which contains elevated levels of chloride and aluminum relative to native soils, affected the germination, growth, and tissue concentrations of various elements, depending on the type and level of exposure. Germination was inhibited by high concentrations of TFS in soil, but the impact was reduced or eliminated if the TFS was leached with water prior to seed planting. Corn and alfalfa biomass production was reduced in the TFS amended soils relative to controls, and corn grown in soils treated with TFS did not develop kernels. Chloride concentrations in corn and alfalfa grown in TFS amended soils were one to two orders of magnitude greater than controls. To compensate for the charge imbalance associated with the high chloride levels, TFSexposed plants were observed to contain higher concentrations of several cations, although the concentrations were still below recommendations for livestock feed. Foliar applications of TFS had no significant impact on biomass production but did show some slight differences in the elemental composition of leaves relative to controls. Washing the TFS off the leaves after 7 days lessened the impact.

The frequency of the rocket motor testing varies from year to year and the areas impacted by the TFS deposition change from test to test depending on the weather conditions at the time of the test. The results of this study show that there is a potential for impact using the worst 
case scenario evaluated here, but the impact could be mitigated by applying additional irrigation to any deposition impacted crops or by shifting the motor testing schedule to post-harvest times if possible. Preliminary results of ongoing greenhouse studies also indicate that additional fertilizer may help minimize the impact of TFS deposition. The high level of chloride associated with the TFS is likely the main cause of the observed impacts.

\section{Conflicts of interest}

The authors whose names are listed immediately below certify that they have NO affiliations with or involvement in any organization or entity with any financial interest (such as honoraria; educational grants; participation in speakers' bureaus; membership, employment, consultancies, stock ownership, or other equity interest; and expert testimony or patent-licensing arrangements), or nonfinancial interest (such as personal or professional relationships, affiliations, knowledge or beliefs) in the subject matter or materials discussed in this manuscript.

Author names: William J. Doucette, Scout Mendenhall, Laurie S. McNeill, and Justin Heavilin.

\section{Acknowledgments}

This work was funded by ATK Launch Systems and the Utah Water Research Laboratory. The authors would like to thank the following people for their assistance with sample collection (Paul Hancock, Jason Wells, Lynn Summers, Reggie Petersen), greenhouse studies (Bruce Bugbee, Julie Chard, Terri Manwaring, Alec Hay) and sample analysis (Joe Stewart, Tess Guy, and Joan McLean).

\section{Appendix A. Supplementary data}

Supplementary data to this article can be found online at http://dx. doi.org/10.1016/j.scitotenv.2014.02.089.

\section{References}

Abo M, Yonehara H, Yoshimura E. Aluminum stress increases carbon-centered radicals in soybean roots. J Plant Physiol 2010;167:1316-9.

Ali S, Bai P, Zeng F, Cai S, Shamsi IH, Qiu B, et al. The ecotoxicological and interactive effects of chromium and aluminum on growth, oxidative damage and antioxidant enzymes on two barley genotypes differing in Al tolerance. Environ Exp Bot 2011;70:185-91.

Bennet RJ, Breen CM, Fey MV. The effects of aluminium on root cap function and root development in Zea mays L. Environ Exp Bot 1987;27:91-104.

Delhaize E, Ryan PR. Aluminum toxicity and tolerance in plants. Plant Physiol 1995;107: 315-21.

Devine M, Duke SO, Fedtke C. Physiology of herbicide action. Englewood Cliffs, NJ: Prentice Hall; 1993.
Doucette WJ, McNeill LS, Mendenhall S, Hancock PV, Wells JE, Thackeray KJ, et al. The sky is falling: chemical characterization and corrosion evaluation of deposition produced during the static testing of solid rocket motors. Sci Total Environ 2013;447:390-5. Fernández V, Eichert T. Uptake of hydrophilic solutes through plant leaves: current state of knowledge and perspectives of foliar fertilization. Crit Rev Plant Sci 2009;28:36-68.

Fukao T, Bailey-Serres J. Plant responses to hypoxia - is survival a balancing act? Trends Plant Sci 2004;9:449-56.

Isla R, Aragüés R. Response of alfalfa (Medicago sativa L.) to diurnal and nocturnal saline sprinkler irrigations. I: total dry matter and hay quality. Irrig Sci 2009;27:497-505.

Isla R, Aragüés R. Yield and plant ion concentrations in maize (Zea mays L.) subject to diurnal and nocturnal saline sprinkler irrigations. Field Crop Res 2010;116:175-83.

Justin SHFW, Armstrong W. The anatomical characteristics of roots and plant response to soil flooding. New Phytol 1987;106:465-95.

Kinraide TB. Interactions among $\mathrm{Ca}^{2+}, \mathrm{Na}^{+}$and $\mathrm{K}^{+}$in salinity toxicity: quantitative resolution of multiple toxic and ameliorative effects. J Exp Bot 1999:50:1495-505.

Langer $\mathrm{H}$, Cea M, Curaqueo G, Borie F. Influence of aluminum on the growth and organic acid exudation in alfalfa cultivars grown in nutrient solution. J Plant Nutr 2009;32: 618-28.

Marschner H. Mineral nutrition of higher plants. San Diego, CA: Academic Press Inc. 1995.

Marschner P. Marschner's mineral nutrition of higher plants. Waltham, MA: Academic Press; 2012.

Melgar JC, Benlloch M, Fernandez-Escobar R. Calcium starvation increases salt susceptibility in olive plants but has no effect on susceptibility to water stress. J Hortic Sci Biotechnol 2007;82:622-6.

Miyasaka SC, Kochian LV, Shaff JE, Foy CD. Mechanisms of aluminum tolerance in wheat: an investigation of genotypic differences in rhizosphere $\mathrm{pH}, \mathrm{K}^{+}$, and $\mathrm{H}^{+}$transport and root-cell membrane potentials. Plant Physiol 1989;91:1188-96.

Mora ML, Schnettler B, Demanet R. Effect of liming and gypsum on soil chemistry, yield, and mineral composition of ryegrass grown in an acidic Andisol. Commun Soil Sci Plant Anal 1999;30:1251-66.

Munns R. Comparative physiology of salt and water stress. Plant Cell Environ 2002;25: 239-50.

National Research Council. Mineral tolerances of animals. Washington DC: National Academies Press; 2005

Noack SR, McBeath TM, McLaughlin MJ. Potential for foliar phosphorus fertilisation of dryland cereal crops: a review. Crop Pasture Sci 2010;61:659-69.

Taiz L, Zeiger E. Plant physiology. Sunderland, MA: Sinauer Associates Inc.; 2006.

Tattini M, Traversi ML. Responses to changes in $\mathrm{Ca}^{2+}$ supply in two Mediterranean evergreens, Phillyrea latifolia and Pistacia lentiscus, during salinity stress and subsequent relief. Ann Bot 2008;102:609-22.

Tavakkoli E, Rengasamy P, McDonald GK. High concentrations of $\mathrm{Na}^{+}$and $\mathrm{Cl}^{-}$ions in soil solution have simultaneous detrimental effects on growth of faba bean under salinity stress. J Exp Bot 2010;61:4449-59.

Torabi M, Halim RA, Sinniah UR, Choukan R. Influence of salinity on the germination of Iranian alfalfa ecotypes. Afr J Agric Res 2011;6:4624-30.

U.S. Environmental Protection Agency. Test method 600/3-88/029: lettuce seed germination. Washington DC: USEPA; 1987.

U.S. Environmental Protection Agency. Method 3050B: acid digestion of sediments, sludges, and soils. In: U.S. Environmental Protection Agency, editor. SW-846: test methods for evaluating solid waste, physical/chemical methods. Washington DC: US EPA; 2012a.

U.S. Environmental Protection Agency. Method 6020A: inductively coupled plasma-mass spectrometry. In: U.S. Environmental Protection Agency, editor. SW-846: test methods for evaluating solid waste, physical/chemical methods. Washington DC: US EPA; 2012b.

US Environmental Protection Agency. Fate, transport and transformation test guidelines: OPPTS 835.1240 leaching studies. Washington DC: USEPA; 2008.

White PJ, Broadley MR. Chloride in soils and its uptake and movement within the plant: a review. Ann Bot 2001;88:967-88. 